\title{
Enhancing Critical Thinking and Problem Solving Ability Through the Implementation of the Research- Based Learning Model in Higher Education
}

\author{
$1^{\text {st }}$ Rohani $^{1}, 2^{\text {nd }}$ Fitra Delita ${ }^{2}, 3^{\text {rd }}$ Eni Yuniastuti ${ }^{3}, 4^{\text {th }}$ Rosni $^{4}, 5^{\text {th }}$ M. Arif ${ }^{5}, 6^{\text {th }}$ M. Farouq \\ Ghazali Matondang ${ }^{6}$ \\ \{rohanispdmsi@gmail.com ${ }^{1}$, delitafitra@gmail.com ${ }^{2}$, eniyuniastuti@gmail.com³ \\ Departement of Geography Education, Faculty of Social Sciences, Universitas Negeri Medan, \\ Indonesia ${ }^{1,2,3,4,5,6}$
}

\begin{abstract}
Critical thinking and problem-solving ability as part of higher-order thinking skills (HOTS) can be improved through learning that facilitates students to interact and work together. The purpose of this study is to describe enhances critical thinking and problem solving ability among students. This research used a pre-experimental method with pretest and posttest group. The pretest and posttest test data were analyzed and the average $\mathrm{N}$-gain was calculated to determine the increase in critical thinking and problem solving abilities after the application of Research-Based Learning. The results of the research indicate that the implementation of Research-Based Learning can develop critical thinking skills and problem-solving ability. It is proved by the fact that the students were able to show their interpretation, analysis, evaluation, inference, and explanation abilities as indicators of critical thinking. Also, the students able to understanding the problem, devising a plan, carrying out the plan (indicators of the problem-solving ability).
\end{abstract}

Keywords: critical thinking, problem-solving ability, research-based learning.

\section{Introduction}

Higher education has important role in the development of science beyond its academic perspective. It also has a broad impact on the life of the global community. It is only proper that college graduates bring a positive atmosphere in solving the problems of human condition [1]. In fact, various new problems have arisen along with the increasingly rapid development of technology, and the list of social and economic problems facing the community only grew longer during the Covid-19 pandemic [2][3][4]. For this reason, learning activities in higher education settings must enable the development of competencies required in the present as well as in the future. Such competencies include critical thinking, creativity and innovation, the ability to communicate and work together[5]. Critical, creative and innovative thinking competencies are part of the higher-thinking skill which fosters problem-solving ability[6].

Higher education must be able to facilitate and create a conducive learning atmosphere for developing student potentials. The learning process must be in accordance with the principles of adult learning. In general, students as functioning adults have a broad mindset and are able to combine existing theories and experiences; they are also interested in something new and challenging and have a higher level of curiosity. Research-based learning is therefore the 
effective strategy to implement in this case. Research-based learning model is a form of paradigm shift in higher education, which will provide a more meaningful and contextual learning experience [7][8][9]. Research-based learning can balance the relationship between theory and practice, and even produce tangible outputs in the form of scientific publications.

The purpose of this study is to describe the improvement of students' critical thinking and problem solving abilities through implementation of research-based learning. The results of this study reinforce the hypothesis that Research-Based Learning is capable of building a positive mentality and improve the students' research abilities, especially in the fields of critical thinking and problem solving. The focus of this research is population issues during the Covid-19 pandemic, which is one of the topics studied in the Seminar Geography course.

\section{Method}

This study makes use of a pre-experimental method with pretest and posttest group. The research subjects were a class of Seminar Geography Course in the Department of Geography Education, State University of Medan, with a total of 28 students. Instruments used for measuring critical thinking and problem solving abilities were tests (pretest and posttest) consisting of 5 questions on critical thinking and 5 questions on problem solving. Critical thinking indicators in this study include interpretation, analysis, evaluation, inference and explanation, while problem solving indicators include visualization of the problem, physical description of issue, planning the solution, implementation, and verificationas well as evaluation of each item. The validity of instruments was confirmed by a team of experts. The pretest and posttest test data were analyzed and the average $\mathrm{N}$-gain was calculated to determine the increase in critical thinking and problem solving abilities after the application of Research-Based Learning.

\section{Results and Discussion}

\subsection{Critical Thinking}

The average pretest and posttest results on each indicator of critical thinking can be observed in the following Table 1:

Table 1. Result of Pretest, Posstest, Gain and N-Gain.

\begin{tabular}{lrlll}
\hline \multicolumn{1}{c}{ Indicator } & Pretest & Posttest & Gain & N-Gain \\
\hline Interpretation & 41.46 & 83.55 & 42.09 & 0.72 \\
Analysis & 52.54 & 84.39 & 31.85 & 0.67 \\
Evaluation & 39.82 & 78.92 & 39.10 & 0.65 \\
Inference & 40.91 & 80.76 & 39.85 & 0.67 \\
Explanation & 47.33 & 88.72 & 41.39 & 0.79 \\
\hline
\end{tabular}


Table 1 shows that there has been an increase in each critical thinking indicator with varying Gain and N-Gain values. N-Gain (g) on indicator analysis (0.67), evaluation (0.65) and inference (0.67) are in the medium category. Meanwhile, N-Gain is high in the indicator interpretation (0.72) and explanation (0.79). This indicates that Research-Based Learning can improve students' critical thinking skills.

\subsection{Problem Solving Ability}

The average pretest and posttest results on each indicator of problem solving ability can be observed in the following Table 2:

Table 2. Result of Pretest, Posstest, Gain and N-Gain.

\begin{tabular}{lrccc}
\hline \multicolumn{1}{c}{ Indicator } & Pretest & Posttest & Gain & N-Gain \\
\hline $\begin{array}{l}\text { visualize the problem } \\
\text { describe the issue in }\end{array}$ & 45.65 & 89.73 & 44.08 & 0.81 \\
$\begin{array}{l}\text { physics description } \\
\text { Plan the solution }\end{array}$ & 34.63 & 84.89 & 41.68 & 0.77 \\
$\begin{array}{l}\text { Carry out the plan } \\
\begin{array}{l}\text { Check and evaluate } \\
\text { the solution }\end{array}\end{array}$ & 37.84 & 82.19 & 49.76 & 0.76 \\
\hline
\end{tabular}

Based on table 2, the fifth indicator with N-Gain (g) 0.68 is in the medium category, while other indicators are in the high category. This shows that overall students' problem solving abilities have increased with the implementation of Research-Based Learning.

Research-Based Learning (RBL) can be integrated in each lecture session using the following strategies: (1) enriching learning material usingresults of research by the lecturer concerned and other relevant research, (2) prioritizing the latest and most recent research results, (3) teaches research methods in accordance with the scope of subject matter, (4) involving students in research activities through mini research assignments and encourages their involvement in lecturers' research, and (5) instilling values in research such as objectivity, honesty, respect for other research and etc., which is in line with the strategies formulated by [10] [11]. Learning systems like this have been widely implemented in various prominent universities around the world [12]. The implementation of Research-Based Learning has improved the students' critical thinking and problem solving skills related to Demography and Population Geography courses. This increase in critical thinking skills occurs in every indicator, namely interpretation, analysis, evaluation, inference and explanation. Among these indicators, the lowest score is given to evaluation. This means that the student's ability to evaluate a problem remains low. Meanwhile, for indicators on problem solving abilities, the lowest N-Gain is given to check and evaluate the solution. The ability of students is still low in terms of re-evaluating solutions that have been formulated regarding population problems. These high-order thinking skills and problem solving tend to have low scores at the next stage/indicator. This is because higher-order thinking processes and problem solving are interrelated with the previous steps [13] [14] [15]. 


\section{Conclusion}

Research-based materials and activities can improve students' critical thinking skills and problem solving. This ability increase occurs gradually on each indicator. For this reason, the application of research-based learning needs to be applied and evaluated on an ongoing basis in order to have a broader and deeper positive impact. This positive impact will be seen in the learning process and learning outcomes in terms of knowledge, attitudes and psychomotor aspects. Increasing critical thinking skills and problem solving in higher education is very appropriate through research-based learning. In addition, this learning model will produce research outputs in the form of research reports and scientific articles. The results of student research, either individually, in groups or in joint research with lecturers, can be seminars and published in scientific forums such as proceedings and journals. The results of this research can even be used as a book containing a collection of student research on certain topics. Learning systems like this are very much in line with the learning paradigm of the $21 \mathrm{st}$ century.

Acknowledgments. We are grateful to the Research and Community Service Institute Universitas Negeri Medan for funding this study.

\section{References}

[1] Duron R, Limbach B, Waugh W. Critical Thinking Framework for Any Discipline. Int J Teaching and Learning in Higher Education (IJTHLE). 2006; 17(2):160-166.

[2] Celuch K, Slama M. Teaching critical thinking skills for the 21st century: An advertising principles case study. J Edu for Business. 1999; 74(3):134.

[3] Eberly Center. Learning Principles Theory and Research-based Principles of Learning. Available from: https://www.cmu.edu/teaching/principles/learning.html [Accessed 10th June 2020].

[4] Brown MN, Kelley. Asking the right questions: A guide to critical thinking. $7^{\text {th }}$ Edition. Englewood Cliffs, NJ: Prentice Hall; 1986.

[5] Arends RI. Learning to Teach. Translated by Helly Prayitno and Sri Mulyantini Soetjipto. Yogyakarta: Pustaka Pelajar; 2008.

[6] Ganio LM. Teaching Critical Thinking (in Statistics) for Natural Resource Education. [Presentation] $8^{\text {th }}$ Biennial Conference on University Education in Natural Resources. 2010.

[7] Peter T. Research-based Teaching and Learning, A LERU project. Munich: University of Zurich; 2010.

[8] Ennis RH. Critical thinking assessment. Theory Into Practice. 1983; 32(3):179-186.

[9] Hannon S, McBride, Burns. Developing creative and critical thinking abilities in business graduates: The value of experiential learning techniques. Industry and Higher Education. 2004; 18(2):95-100.

[10] Bastiaens E. Three Educational Models for Positioning the Maastricht Research-Based Learning Programme. Maastricht: Springer; 2017.

[11] Alison G. Griffith Institute for Higher Education (GIHE), Good Practice Guide on Research-Based Learning. Brisbane: Griffith University.

[12] Healey M, Jenkins A, Lea J. Developing Research-Based Curricula in College-Based Higher Education. New York: The Higher Education Academy; 2014.

[13] Mujis D, Reynolds D. Effective Teaching. London: Sage Publications; 2008.

[14] Berutu N, Delita F, Astuti AJD, Novira N, Wirda MA. The Strategy To Strengthen Information Literacy Based On Library and Digital Resources. Proceedings of the $1^{\text {st }}$ International Conference on Social Sciences and Interdisciplinary Studies (ICSSIS 2018); $14^{\text {th }}-15^{\text {th }}$ November 2018; Medan. Atlantis Press; 2019. p. 144-147. 
[15] Delita F, Arif M, Rosni, Sitompul M, Rohani. Improving The Quality of Learning Through Assignment System. J Phys: Conf Ser. 2019; 1175:1-4. 